\title{
Research
}

\section{Dietary Changes over Time in a Caiçara Community from the Brazilian Atlantic Forest}

\author{
Priscila L. MacCord $^{1}$ and Alpina Begossi ${ }^{1}$
}

\begin{abstract}
Because they are occurring at an accelerated pace, changes in the livelihoods of local coastal communities, including nutritional aspects, have been a subject of interest in human ecology. The aim of this study is to explore the dietary changes, particularly in the consumption of animal protein, that have taken place in Puruba Beach, a rural community of caiçaras on the São Paulo Coast, Brazil, over the 10yr period from 1992-1993 to 2002-2003. Data were collected during six months in 1992-1993 and during the same months in 2002-2003 using the 24-hr recall method. We found an increasing dependence on external products in the most recent period, along with a reduction in fish consumption and in the number of fish species eaten. These changes, possibly associated with other nonmeasured factors such as overfishing and unplanned tourism, may cause food delocalization and a reduction in the use of natural resources. Although the consequences for conservation efforts in the Atlantic Forest and the survival of the caiçaras must still be evaluated, these local inhabitants may be finding a way to reconcile both the old and the new dietary patterns by keeping their houses in the community while looking for sources of income other than natural resources. The prospect shown here may reveal facets that can influence the maintenance of this and other communities undergoing similar processes by, for example, shedding some light on the ecological and economical processes that may occur within their environment and in turn affect the conservation of the resources upon which the local inhabitants depend.
\end{abstract}

Key Words: Atlantic Forest ; Brazil; caiçara; social-ecological resilience; dietary change; fish consumption; animal protein; food delocalization; niche breadth

\section{INTRODUCTION}

Food utilization, a basic concern in all human societies, attracts the attention of scientists from many different areas (Messer 1984, Gossard and York 2003). From the perspective of human ecology, analysis of the nutritional patterns and diet of a given population may reveal how these factors affect the use of local resources (Colding and Folke 1997, McDonald 1977, Begossi et al. 2004) and environmental sustainability (Goodland 1997). Even when part of the food consumed by a given local population is available in their environment, their consumption of it is not usually proportional to its local availability (Hawkes et al. 1982). Other factors can also contribute to consumption patterns, such as market accessibility, preferences, social factors, and the costs and benefits of pursuing and capturing food items in natural environments (Stephen and Krebs 1986, Dufour and Teufel 1995).
Moreover, in small societies, especially in rural and indigenous populations, food habits can be profoundly linked to traditional subsistence patterns (Murrieta et al. 1993, 1999, Fa et al. 2002).

Food self-sufficiency in rural Brazilian communities is being continuously reduced because of the growth of urbanization and the change from artisanal cultivation methods to commercial ones (Murrieta et al. 1999). Besides increasing the dependence of local populations on externally purchased products and altering their relationship with local resources, such changes can affect the nutritional status of a population, with a resulting decrease in the types of food eaten (Fleuret and Fleuret 1980, Pelto and Pelto 1983).

One way of analyzing the relationship between diet and changes in the use of resources by human groups is from an ecological perspective such as Optimal 
Foraging Theory or OFT (Smith 1983, Durrenberger and Pálsson 1986). OFT asserts that human choices aim to maximize the net rate of energy gain, a measure of fitness (Krebs and McCleery 1984). According to the diet-breadth model that forms part of OFT, foragers choose their diets based on the abundance of different items in the environment, the amount of energy necessary to acquire an item vs. the energy produced by it, and the amount of time needed to manipulate the item (Bettinger 1991). Therefore, the resource that a forager would most prefer to exploit may not be included in his/her diet if it is rarely found, inasmuch as this would result in a low rate of return. We can measure this using the niche concept. The classical definition of niche (Hutchinson 1957) is represented by a hypervolume, meaning that it has "multidimensions," such as all the environmental variables, conditions, and resources needed by an organism. Considering, for example, the animals consumed by one population as one niche dimension, the niche width might be narrower if the forager finds his/her preferred animal items; if not, it is broader.

Understanding the use of resources by small-scale communities living on the Brazilian coast is a necessary step for achieving needed local conservation of forested sites, such as the Atlantic Forest, as well as the associated bodies of water. Moreover, such an understanding might help elucidate the market consequences for the local fishing communities, because these communities are responsible for 40-60\% of all Brazilian marine fish production (Silvano 2004). Furthermore, such communities are located on sites with high biodiversity values, and changes in the way of life of these people may have direct impacts on the local environment. Evaluating such changes may help us to anticipate scenarios of possible consequences, allowing a beforehand decision-making process by stakeholders, when and if necessary. Despite the recognized importance of humans as environmental agents or modifiers (Geist and Lambin 2001), only a few studies have attempted to observe the consequences of transitional processes for the use of resources. Most studies focus on later environmental and/or social effects, such as game depletion (Alvard et al. 1997), habitat modification (Happoled 1995), or the rise in poverty (Ezra 2001). In this Brazilian case study, we show how simple and standard, widely used methods applied to dietary studies can reveal the scenarios resulting from the ongoing changes and discuss possible future environmental consequences that may be relevant for conservation practices. We investigate the food habits of the fishermen's families who inhabit Puruba Beach, a rural coastal community in southeastern Brazil, and evaluate the changes that occurred in their dietary patterns, especially with regard to animal protein, from 1992-1993 to 20022003. The hypothesis outlined here, which is in accordance with the ecological literature and based on data on food preferences, is that nowadays this population eats a great diversity of animal protein because of the reduction in the number of fish species traditionally used in their diet, on the grounds that the scarcity of the preferred food should lead to a more generalist diet. The results found here may be the only data available on dietary changes over time in communities of caiçaras, the name given to the descendents of Portuguese settlers and Indians who inhabit the coastal areas of the Atlantic Forest in Brazil (Begossi 2006), and may shed some light on the recent transformations that this type of Brazilian coastal communitiy has undergone. Moreover, because such changes are becoming commonplace not only in coastal communities (Baird and Flaherty 2005, Neiland et al. 2000) but also further inland, the hypotheses and conclusions derived here may be applicable to similar groups in Brazil and anywhere else in the world that local communities keep some of their old management systems but are threatened by unplanned development or resource exploitation.

\section{METHODS}

The community of Puruba Beach is located on the coast of the Atlantic Forest in Brazil's São Paulo State at these coordinates: $23^{\circ} 21^{\prime} 02^{\prime} ' \mathrm{~S}$ and $44^{\circ}$ 55'09' ' $\mathrm{W}$. The community is bordered by a state park, the Parque Estadual da Serra do Mar, which was created in 1977. The establishment of this park led to restrictions on the use of resources by the inhabitants, such as prohibitions against some of the traditional methods used in agriculture, e.g., slash and burn, and in fishing, e.g., the use of nets on the rivers, without providing alternative means of subsistence. In 1992-1993, 14 families made up this community, and by 2002-2003 the number had increased to 22, four of them families of tourists who had abandoned their former lives in large cities. One consequence of factors such as contact with outside people, the improvement in welfare services, and the environmental laws and restrictions imposed by the state park was that the 
local inhabitants were forced to develop new habits or find substitutes for old ones. For instance, cassava cultivation is no longer practiced at this location, and cheap processed foods are becoming part of the daily diet. Once the residents could no longer carry out traditional rural activities, many of the local population looked for jobs in the closest major city, Ubatuba, about $20 \mathrm{~km}$ from Puruba Beach, but a few of them moved to other places, mainly because there are still portions of land being shared among the sons and daughters of the original inhabitants.

To investigate the diet of the inhabitants of Puruba Beach, we chose seven domestic units in 20022003, which corresponded to all the local families that still included an active fisherman who still fished, at least sporadically. Data were collected during 10-day periods each month for a total of six months (October and November of 2002; January, February, May, and June of 2003), using the 24-hr recall method (Dufour and Teufel 1995). Every day we registered the food consumption of all members of the domestic units at the two main meals, lunch and dinner. To compare the changes that occurred during a 10-yr interval, we used the data collected by means of an identical methodology in 1992-1993 and corresponding to the same six months (Begossi 1995). However, in 1992-1993, only data concerning the consumption of animal protein were collected. In 1992-1993, Begossi (1995) collected data on 12 families, three of which were also present during the second period, but with a different composition because of marriage and the birth of children. Data on the animal protein preferences of the residents and on fish landings were also collected in 1992-1993, which made it possible to compare recent choices and changes and to investigate the relationship between fishing and diet during this time. We used a Partition Qui-Square to identify alterations in the frequency of protein consumption. The relationship between fishing and fish consumption was analyzed through Spearman's coefficient of rate correlation using (1) the mass $(\mathrm{kg})$ of fish caught or the number of fish landings in which the most important species, i.e., those representing at least $3 \%$ of the catch in mass or in presence in the catch, were present and (2) the frequency of fish consumption. We used Morisita's similarity index to compare food consumption between the two studies. We also used diversity measures, specifically rarefaction curves and the Shannon-Wiener index, to analyze the niche breadth (Hardesty 1975) and to assess the frequency of fish items and other animal products (Appendix 1).

\section{RESULTS}

We collected data on 1323 meals in 1992-1993 and 603 meals in 2002-2003. The average of meals registered monthly was $209( \pm 9.92)$ in $1992-1993$ and $100( \pm 31.73)$ in 2002-2003. In 2002-2003, 83\% of the the meals included rice; $80 \%$, beans; $77 \%$, some type of pasta, particularly spaghetti; $51 \%$, vegetables and leaf vegetables; and $30 \%$, cassava flour. Comparable data are not available for the first period. Animal protein was present in $92 \%$ and $88 \%$ of the meals in the first and second periods, respectively; this difference is significant when compared on a monthly basis $\left(\chi^{2}=32.62, \mathrm{df}=5, p\right.$ $<0.001)$.

We observed significant changes between the two studies with regard to the kinds of animal protein consumed $\left(\chi^{2}=68.16 ; \mathrm{df}=7, p=0.00\right)$, mainly because of the replacement of fish, whose proportion of animal protein consumption dropped from 42 to $34 \%\left(\chi^{2 \text { Partition }}{ }_{\text {fish }}=7.07, \mathrm{df}=1, p=0.00\right)$, by other alternatives bought externally, especially beef $\left(\chi^{2 \text { Partition }}{ }_{\text {beef }}=45.73, \mathrm{df}=1, p=0.00\right)$, whose proportion grew from 18 to $30 \%$. However, in 2002 2003 fish was still the main animal protein source for this community. Meals without any kind of animal protein represented only $8 \%$ of the meals in the first period and $12 \%$ in the second $\left(\chi^{2 \text { Partition }}{ }_{\text {noAP }}\right.$ $=5.61, \mathrm{df}=1, p=0.02$ ).

Using data on meat preference collected in 1991 ( $n$ $=20$ interviewees), we observed that the local residents had a slight preference for fish over beef, with $45 \%$ of those interviewed preferring fish and $40 \%$ preferring beef.

Although the two periods were very similar in terms of the fish species most consumed $\left(C_{\mathrm{H}}=0.69\right)$, it should be noted that the consumption of catfishes and white mullets ( $M$. curema) decreased during the second period, whereas mullet (M. platanus) consumption nearly quadrupled. Fishes of moderate importance in the first period, such as horse-eye jack (Caranx latus) and whitemouth croaker and sand drum (Micropogonias furnieri and Umbrina coroides), were rarely consumed during the second one (Table 1).

When we associated fish consumption with fish availability from the fishery, we observed that, in the past, these values were positively correlated in three of the six months studied: February, May, and June (Fig. 1). January presented a very high average, 
Table 1. Percentage of fish consumption in 1992-1993 and 2002-2003; $n$ refers to the total number of meals that included some kind of fish as animal protein, $\mathrm{NC}=$ not collected.

\begin{tabular}{|c|c|c|c|}
\hline Common name & Scientific name & $\begin{array}{c}\text { Percentage of } \\
\text { consumption 1992-1993 } \\
(n=554)\end{array}$ & $\begin{array}{l}\text { Percentage of } \\
\text { consumption 2002- } \\
2003(n=208)\end{array}$ \\
\hline Atlantic bumper & Chloroscombrus chrysurus & 0.7 & 0.0 \\
\hline Atlantic cutlass fish & Trichiurus lepturus & 3.4 & 4.3 \\
\hline Black margate & Anisotremus surinamensis & 1.3 & 1.9 \\
\hline Bluefish & Pomatomus saltatrix & 0.4 & 0.0 \\
\hline Guri sea catfish & Genidens genidens & 9.4 & 4.8 \\
\hline Cichlid & Geophagus spp. & 0.7 & 0.0 \\
\hline Crevalle jack & Caranx hippos & 0.2 & 0.0 \\
\hline Flagfin & Eucinostomus melanopterus & 0.7 & 1.9 \\
\hline Florida pompano & Trachinotus carolinus & 0.2 & 0.0 \\
\hline Gray snapper & Lutjanus griseus & 1.3 & 5.8 \\
\hline Gray triggerfish & Balistes capriscus & 0.2 & 0.0 \\
\hline Grouper & Epinephelus marginatus & 0.7 & 0.0 \\
\hline Horse-eye jack & Caranx latus & 3.1 & 0.0 \\
\hline Jamaica weakfish & Cynoscion jamaicensis & 0.5 & 0.0 \\
\hline Kingcroaker & $\begin{array}{l}\text { Menticirrhus littoralis, } M . \\
\text { americanus }\end{array}$ & 1.4 & 2.4 \\
\hline Lane snapper & Lutjanus synagris & 1.8 & 1.0 \\
\hline Leatherjack & Oligoplites spp & 0.2 & 0.0 \\
\hline Mojarra spp. & Diapterus olisthostomus & 1.1 & 2.4 \\
\hline Mullet & Mugil platanus & 5.4 & 19.7 \\
\hline Pompano & Trachinotus spp & 0.2 & 1.0 \\
\hline Porkfish & Anisotremus virginicus & 0.4 & 1.0 \\
\hline Scad & $\begin{array}{l}\text { Tachurus lathami; Decapterus spp; } \\
\text { Caranx latus }\end{array}$ & 0.5 & 1.0 \\
\hline Shark & Carcharhinidae & 1.6 & 1.0 \\
\hline Sheepshead porgy & Calamus penna & 0.0 & 10.6 \\
\hline
\end{tabular}




\begin{tabular}{llcc}
\hline Small fish & Juveniles of many species & 0.4 & 0.0 \\
Snook & Centropomus spp. & 18.2 & 16.8 \\
Weakfish & NC & 0.2 & 0.0 \\
Weakfish & Cynoscion spp; Macrodon spp & 0.0 & 1.9 \\
White mullet & Mugil curema & 40.1 & 14.9 \\
Whitemouth croaker/ & Micropogonias furnieri; Umbrina & 3.1 & 0.5 \\
Sand drum & coroides & & 0.0 \\
Yellow chub & Kyphosus sectatrix & 0.5 & 3.8 \\
Other species & NC & 0.9 & 0.0 \\
Juveniles & NC & 0.4 & 0.0 \\
Oysters & Crassostrea spp. & 0.2 & 2.4 \\
Shrimp & Macrobrachium spp. & 0.4 & 0.0 \\
Shellfish & NC & 0.7 & 1.0 \\
Squid & Loligo spp. & 0.0 & \\
& & & \\
\hline
\end{tabular}

but the standard error ( $\mathrm{SE}=28.1)$ is also extremely elevated because of the low numbers of fishing trips with high return in mass (Fig. 1). In the second period (Fig. 2), fish consumption changed according to fishery, even during October, when it is possible to observe a largely unpredictable fishery given the high standard error $(\mathrm{SE}=15.9)$. In this case, it was observed that just one fishing trip was responsible for the high return, with the capture of $180 \mathrm{~kg}$ of gray snapper (Lutjanus griseus), which was shared among all the households in the community.

Using data obtained from fish landings through Spearman's correlation, it was possible to determine if the most common fishes, in terms of biomass and frequency in fish landings, were also the ones most consumed (Table 2). In 1992-1993, we did not observe a significant correlation between the consumption and mass $(\mathrm{kg})$ of fish caught, although there was a significant correlation between diet and number of fishing trips in which the fishes were present $(p=0.03)$. The same analysis, when carried out for 2002-2003, did not reveal any significant correlation, although there was some indication of a trend $(p=0.07)$ between diet and number of fishing trips (Table 2).
There was no significant difference between the two periods with regard to the diversity of animal protein items consumed (Shannon $H^{\prime}{ }_{1992-1993}=2.517$, $\left.H_{2002-2003}^{\prime}=2.488, t=-0.43 ; \mathrm{gl}=1046, p>0.05\right)$. However, when we consider just fish species, their diversity in 2002-2003 was significantly higher than in 1992-1993 $\left(H^{\prime}{ }_{1992-1993}=2.244, H^{\prime}{ }_{2002-2003}=\right.$ $2.563, t=3.41, \mathrm{gl}=532, p<0.01$ ), even though the expected richness, i.e., number of species, was lower, as can be observed in the rarefaction curve (Fig. 3, Table A.1). This means that, although a wider variety of fish species was consumed in the first period, few species were eaten more frequently. On the other hand, the higher diversity index of the second period suggests a more equalitarian distribution of the number of times each fish is eaten.

\section{DISCUSSION}

In this study, we demonstrate a shift in protein consumption evidenced by the observed reduction in the frequency of animal protein consumption and changes in the type of animal protein consumed (fish or beef). Although the observed dietary changes could be indicative of a better economic situation 
Fig. 1. Relationship between the average amount of fish caught on each trip per month and monthly consumption of fish in 1992-1993.

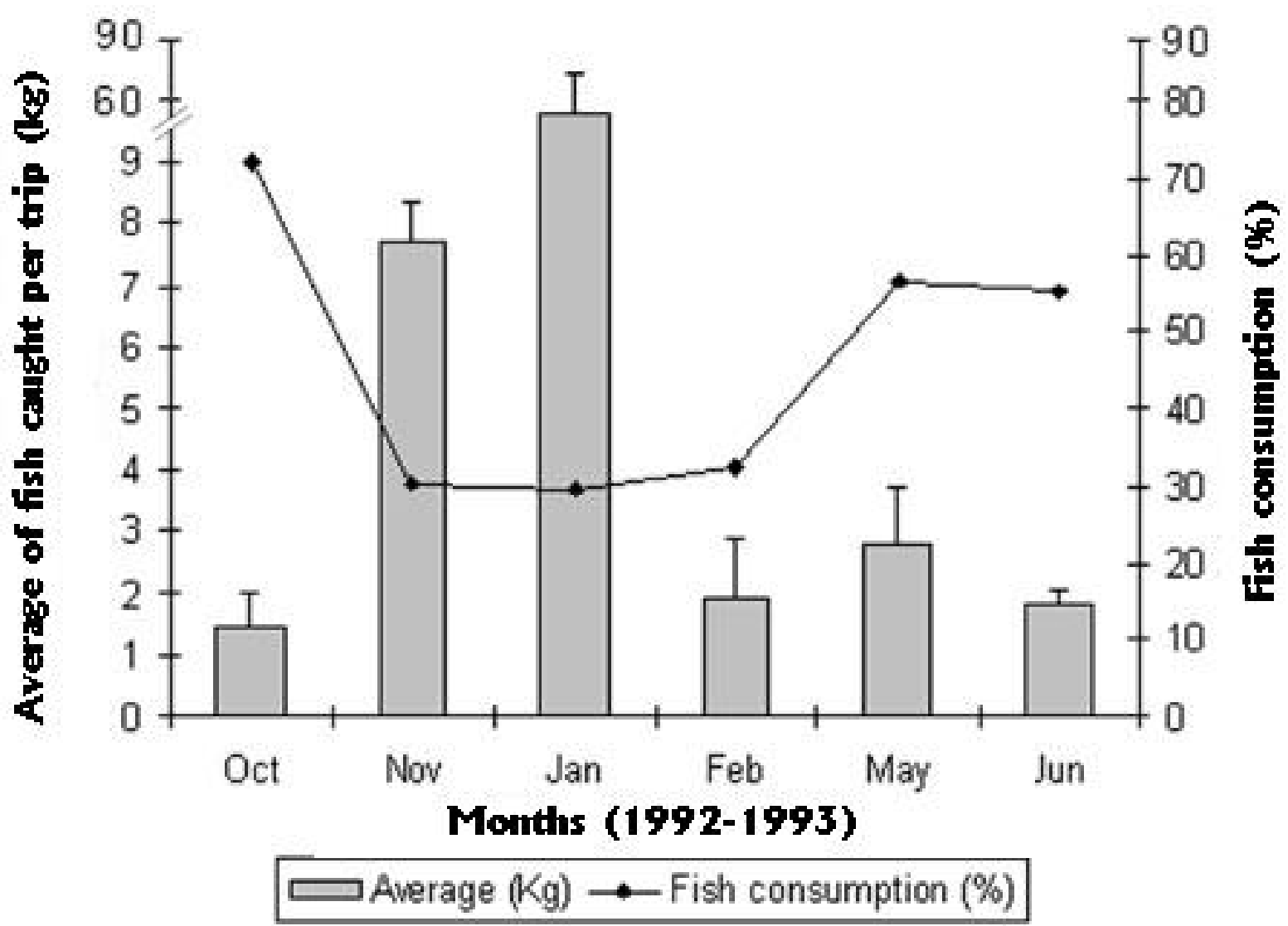

for caiçaras, our data on preference do not corroborate this hypothesis. For example, if Puruba residents had always preferred beef to fish, even a slight improvement in the local economy would have encouraged them to consume more beef in the recent period. However, data on food preferences suggest that both types of meat, fish and beef, are very much appreciated, with a slight preference for fish. This is contrary to what has been observed, for example, on the northern coast of Brazil, where other kinds of meat replace fish on special occasions (Murrieta et al. 1999). Moreover, at Puruba, fish is a resource that can be gathered at no cost, whereas beef still costs money.

The reduction or disappearance of some fish species from the diet is intriguing, and we can only speculate as to the cause. Although the damage done by shrimp trawling, especially to fish species inhabiting the sandy bottom (Amezcua et al. 2006), is one possible reason, there is not much shrimp fishing in the local waters close to the beach. A more likely explanation is that, because of the prohibitions in the legislation governing the state park, the local fishermen restricted the use of nets near the beach, the main habitat of most of these species.

An increase in the dependence on external food and a decrease in the consumption of local natural resources were evident in the lower consumption of eggs and the higher consumption of beef instead of fish. Surveys conducted in communities of caiçaras and the caboclos who live along the Amazon River show that the consumption of fish is usually much higher, between 65 and 75\% (Begossi 1995, 
Fig. 2. Relationship between the average amount of fish caught on each trip per month and monthly consumption of fish in 2002-2003.

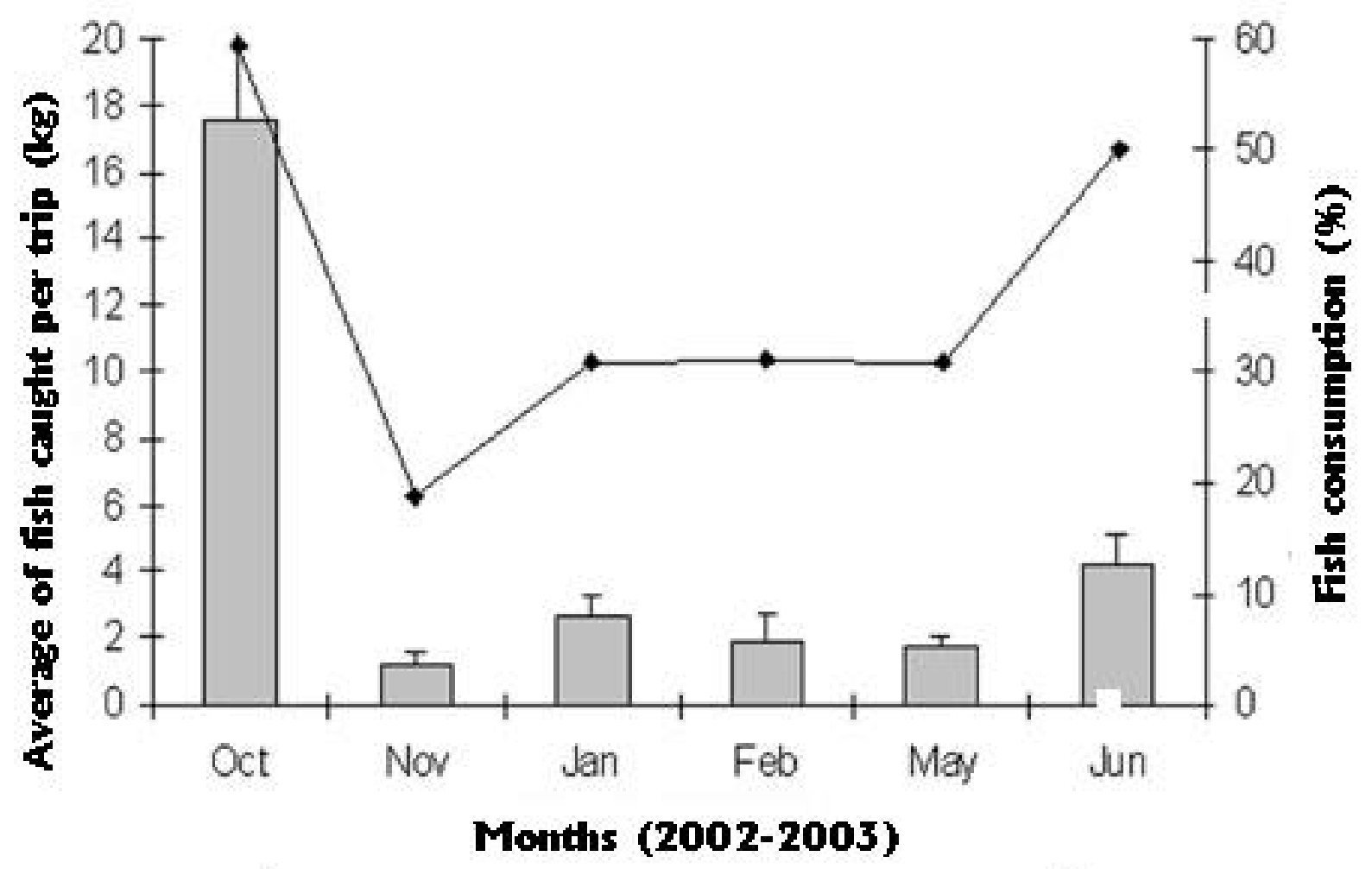

Average $(\mathrm{Kg}) \rightarrow$ Fish consumption $(\%)$

Murrieta et al. 1999, Begossi et al. 2004) than the values found for Puruba Beach. However, in recent studies carried out in other caiçara and caboclo communities, it was observed that marketed products were gradually replacing fish, even though fish was still the main source of animal protein (Hanazaki and Begossi 2003; A. L. Silva and A. Begossi, unpublished manuscript). The importance of external products in the diet is controversial. Studies in Africa showed that the consumption of purchased meals could enrich children's diets as long as they did not have access to low-nutrient western food (Ferguson et al. 1993). Conversely, Benefice and Barral (1991) compared the nutritional status of settlers and Siona-Secoya Indians living in the same habitat in the Amazon and found great discrepancies between them; the settlers' diet was quite inferior. In Puruba, fishes come mainly from the estuary, generally from unpolluted areas with little or no sewage discharge. With meat, however, there is only dubious quality control from production, which relies heavily on antibiotics and hormones, to the marketplace, which can be extremely unhygienic. Because of this, dietary changes that favour beef over fish may eventually compromise the quality of the local diet in addition to making it more expensive to obtain. It would be necessary to follow the dietary practices and preferences of this population for a longer period to conduct a long-term temporal analysis.

Elucidating the relationship between the local fishery and the local diet is another way to make evident the dependence of the community on fishing resources and illustrate seasonal changes. In our survey, fish consumption was strictly related to fish 
Table 2. Spearman's coefficient of rank correlation between the presence of fish items in the diet and the biomass or frequency of fish caught. Fishes considered in 1992-1993 were guri sea catfish, mojarra spp., flagfin, white mullet, snook, mullet, rough scad, and Florida pompano; in 2002-2003, guri sea catfish, mojarra spp., flagfin, white mullet, snook, and mullet. The number of fish landings was 108 in 1992-1993 and 167 in 2002-2003.

\begin{tabular}{|c|c|c|c|c|}
\hline \multirow{2}{*}{$\begin{array}{l}\text { Spearman's } \\
\text { coefficient of } \\
\text { rank correl- } \\
\text { ation }\end{array}$} & \multicolumn{2}{|c|}{ Catch $(\mathrm{kg}) \times$ diet } & \multicolumn{2}{|c|}{ Number of fish landings $\mathrm{x}$ diet } \\
\hline & $1992-1993$ & $2002-2003$ & $1992-1993$ & 2002-2003 \\
\hline$r_{s}$ & 0.20 & 0.40 & 0.75 & 0.70 \\
\hline$p$ & 0.80 & 0.50 & 0.03 & 0.07 \\
\hline
\end{tabular}

landings, varying only in the months in which a few trips had high returns in mass. It is likely that, in these cases, the catch was destined for sale and not for consumption. When we analyzed this same aspect using the main fish species present in fish landings, we observed that there was a close association between diet and occurrence of the species in fish landings, suggesting that consumption followed immediate availability, even if the fish were caught in great amounts. When a huge amount of fish is caught, the fisherman can sell or share the fish with the community, whereas it is possible to keep smaller amounts for a longer time. Such a choice, to eat or to sell, was previously observed in earlier studies along this coast, such as on Búzios Island (Begossi and Richerson 1993).

It is clear that fish consumption varies, in general, according to the catch, which means that fish are eaten when available. Despite that, fish consumption diminished, which, associated with data on meat preference, may suggest a lower abundance of fish at the location. Indeed, there is some evidence for this, because the CPUEs (capture per unit of effort) also changed during these periods (Lopes 2004). Although some months had greater CPUEs in 2002-2003 than in 1992-1993, the difference between the two periods was small. On the other hand, months that had greater CPUEs in 1992-1993 had up to a 30-fold difference. However, it should be noted that the author considered the differences statistically insignificant (Lopes 2004).
Measuring diet selectivity through diversity indexes is a way to measure one niche dimension of a given population. In the case of human populations, it is possible to establish their relationship with other organisms and the way in which the resources are used by estimating the degree of diet generalization or specialization (Begossi and Richerson 1993). Our analyses demonstrated that, in the past, more species were consumed, but people consumed only some of them more frequently, suggesting that factors such as optimal choices, e.g., based on the availability of the most rewarding species, in terms of calories and handling time (Stephens and Krebs 1986), and also food preferences might have influenced these selections (Hanazaki and Begossi 2000). In the most recent period, the prevalence of some species is not as evident as in the past. This result agrees with the diet-breadth model, which states that the number of less-preferred foods should increase if the preferred ones become less abundant, leading to dietary generalization (MacArthur and Pianka 1966, Krebs and McCleery 1984) or a broader niche breadth. This may reinforce the observation that the broader niche breadth in 2002-2003 could be the outcome of a lesser abundance of the preferred species.

The prospect shown here goes beyond dietary and nutritional aspects because it reveals facets that can influence the maintenance of this and other communities undergoing similar processes. For example, we believe that the dietary study presented here helps to elucidate the ecological and economical processes within the Atlantic Forest 
coast that might affect the conservation of the artisanal fisheries along that coast (Begossi 2006). The decrease in economic flexibility caused by the reduced diversity of income sources that resulted from the abandonment of fishing and agriculture could lower the ability of the ecosystem to resist external perturbation (Schläpfer and Schmid 1999), facilitating the occurrence of changes in the system. The accelerated changes that this community is undergoing may eliminate behaviors that could be associated with local resilience (Begossi 2003). However, the fact that the caiçara inhabitants continue to live in the Atlantic Forest while obtaining cash from other sources such as jobs outside the community may help strengthen local resistance and resilience. Even though the outcome for these communities is still unclear, history has shown that the caiçaras are relatively flexible when it comes to adapting to different economic and social cycles (A. Begossi, unpublished manuscript), but this can be limited to how their resilience is affected. The results presented here seem to reinforce the point of view of Gross et al. (1979), who note that, the harder it is for the inhabitants of a community to make a living through traditional means, the greater the extent of their market participation. Wherever communities are undergoing similar processes, market participation seems to be related to the restrictions imposed on the use of local resources or to a reduction in available resources, usually caused by external factors. This may be true for the Philippines (White et al. 2006), Africa (Neiland et al. 2000), Indonesian Malaysia (Siry 2006), and other east coast or riverine areas in which there are still small local communities with traditional management systems living in environments of high biodiversity, but under strong pressure from factors such as forest products exploitation by outside enterprises, increasing tourism, or inappropriately enforced environmental laws. In these places, transitional processes are just the consequences of such pressures. Wherever we find outcomes that are satisfactory from a social and ecological perspective, it remains to be seen if these situations are stable, or if, after a longer period, social consequences such as internal stratification will lead to the dismantlement of such groups.

\section{FUTURE INVESTIGATIONS}

One point that deserves to be investigated in the future is related to an aspect observed only in 20022003: the consumption of cassava flour. This item was not an important meal constituent, although other studies have indicated that this food, together with fish, is one of the main staples of the caiçara diet (Begossi and Richerson 1993, Peroni and Hanazaki 2002). This may be indicative of a trend among the caiçaras, especially those who have extensive contact with urbanized areas and/or are subjected to restrictions in cultivation methods, because this reduction in cassava flour consumption was also observed in other places (Hanazaki and Begossi 2003). At present, restrictions on the use of traditional resources, the introduction of marketed foods, and contact with non-native people are usually considered important contributors to changing diet patterns (Kuhnlein 1992).

\section{CONCLUSIONS}

Investigating the changes that are likely to take place in traditional societies in the future, such as the ones examined in this study, may be a relevant and simple tool that human ecologists can use to anticipate and, if necessary, prevent environmental losses. Furthermore, there are social consequences of such changes that may be relevant to politicy makers. The community of Puruba Beach is passing through a sequence of changes whose manifestations include the acquisiton of features similar to those of urban inhabitants, such as an effective reduction in fish consumption and an increase in the consumption of products acquired externally. Considering only their diet, this may be the outcome of easier access to industrialized food, although we have reason to believe, based on their meat preferences, that ecological factors rather than economic ones may be influencing the most recent changes. In spite of a slight preference for fish over beef, Puruba residents decreased their fish consumption and increased their beef consumption. Environmental factors, such as restrictions on the use of resources imposed by the park, the alteration of estuarine and mangrove habitats, and commercial fishing on the shore by outside fishermen, may account indirectly for part of these dietary changes. We cannot come to a conclusion about the nutritional aspects of the food shifts observed at Puruba Beach, because we did not evaluate the nutritional aspects of the changes observed, although we can speculate about conflicting future outcomes, such as the questionable benefits of consuming meat. We can definitely conclude that the caiçaras increased their dependence on commercialized products and decreased their use of local natural resources. The 
less intensive use of resources brought about by working in the city, but residing in the village may be a way for the inhabitants to conserve the Atlantic Forest without being excluded from the ecosystem. Because government conservation initiatives seem far from ideal, Puruba's inhabitants may have found, although not consciously, a way to reconcile the sustainable use of local resources with their own local survival. We believe that the kind of changes observed here may be found in other caiçara groups and other societies, such as the caboclos and other Amazonian groups, as well as local communities in other tropical areas, such as many of the African and Pacific communities mentioned in the Discussion. However, the way that each one copes with such transformations may be different and depend on ecological, economical, and political factors, including environmental legislation. Dealing with such changes may be a necessary step in understanding and conserving sites with high biodiversity as well as the communities that depend upon local natural resources.

Responses to this article can be read online at:

http://www.ecologyandsociety.org/vol11/iss2/art38/responses/

\section{Acknowledgments:}

We are grateful to CAPES for financial support through the PLM's master grant. We thank FAPESP for research grant 01/05263-2, and CNPq for the productivity scholarship to AB. R.A.M. Silvano collaborated with many valuable suggestions. We thank the caiçara families for their solicitude. We also thank the postgraduate program in Ecology/IB.

\section{LITERATURE CITED}

Alvard, M. S., J. G. Robinson, K. H. Redford, and H. Kaplan. 1997. The sustainability of subsistence hunting in the neotropics. Conservation Biology 11(4):977-982.

Amezcua, F., J. Madrid-Vera, and H. AguirreVillasenor. 2006. Effect of the artisanal shrimp fishery on the ichthyofauna in the coastal lagoon of Santa Maria de la Reforma, southeastern Gulf of California. Ciencias Marinas 32(1B):97-109.
Baird, I. G., and M. S. Flaherty. 2005. Mekong river fish conservation zones in Southern Laos: assessing effectiveness using local ecological knowledge. Environmental Management 36 (3):439-454.

Begossi, A. 1995. The application of ecological theory to human behavior: niche, diversity and optimal foraging. Pages 153-161 in R. Borden, M. Bubolz, L. Hens, J. Taylor, and T. Webler, editors. Human ecology: progress through integrative perspectives. Society for Human Ecology, East Lansing, Michigan, USA.

Begossi, A. 2003. Islanders of the southeastern coast: livelihood, natural resources and resilience. Pages 277-299 in P. F. Vieira, editor. Conservação da diversidade biológica e cultural em zonas costeiras: enfoques e experiências na América Latina e Caribe. Aped Editora, Florianópolis, Brazil.

Begossi, A. 2006. Temporal stability in fishing spots: conservation and co-management in Brazilian artisanal coastal fisheries. Ecology and Society 11(1): 5 [online] URL: http://www.ecology andsociety.org/vol 11/iss1/art5/.

Begossi, A., N. Hanazaki, and R. M. Ramos. 2004. Food chains and the reasons for food fish taboos among Amazonian and Atlantic Forest fishers (Brazil). Ecological Applications 14(5):1334-1343.

Begossi, A., and P. J. Richerson. 1993. Biodiversity, family income and ecological niche: a study of the consumption of animal foods on Búzios Island (Brazil). Ecology of Food and Nutrition 30:51-61.

Benefice, E., and H. Barral. 1991. Differences in life style and nutritional status between settlers and Siona-Secoya Indians living in the same Amazonian milieu. Ecology of Food and Nutrition 24:307-322.

Bettinger, R. L. 1991. Hunter-gatherers as optimal foragers. Pages 83-111 in R. L. Bettinger, editor. Hunter-gatherers: archaeological and evolutionary theory. Plenum Press, New York, New York, USA.

Colding, J., and C. Folke. 1997. The relations among threatened species, their protection, and taboos. Conservation Ecology 1(1):6. [online] URL: http://www.consecol.org/vol1/iss1/art6/. 
Dufour, D. L., and N. I. Teufel. 1995. Minimum data sets for the description of diet and measurement of food intake and nutritional status. Pages 97-128 in E. F. Moran, editor. The comparative analysis of human societies: toward common standards for data collection and reporting. Lynne Rienner Publishers, London, UK.

Durrenberger, E. P., and G. Pálsson. 1986. Finding fish: the tactics of Iceland skippers. American Ethnologist 13(2):213-229.

Ezra, M. 2001. Ecological degradation, rural poverty, and migration in Ethiopia: a contextual analysis. Policy Research Division Working Paper No. 145. Population Council, New York, New York, USA.

Fa, J. E., J. Juste, R. W. Burn, and G. Broad. 2002. Bushmeat consumption and preferences of two ethnic groups in Bioko Island, West Africa. Human Ecology 30(3):397-416.

Ferguson, E. L., R. S. Gibson, C. Opare-Obisaw, F. Osei-Opare, C. Lamba, and S. Ounpuu. 1993. Seasonal food consumption patterns and dietary diversity of rural preschool Ghanaian and Malawian children. Ecology of Food and Nutrition 29:219-234.

Fleuret, A., and P. Fleuret. 1980. Nutrition, consumption and agricultural change. Human Organization 39:250-260.

Goodland, R. 1997. Environmental sustainability in agriculture: diet matters. Ecological Economics 23:189-200.

Gossard, M. H., and R. York. 2003. Social structural influences on meat consumption. Human Ecology Review 10(1):1-9.

Gross, D. R. 1979. Ecology and acculturation among native peoples of Central Brazil. Science 206 (30):1043-1050.

Hanazaki, N., and A. Begossi. 2000. Fishing and niche dimension for food consumption of caiçaras from Ponta do Almada (Brazil). Human Ecology Review 7(2):52-62.

Hanazaki, N., and A. Begossi. 2003. Does fish still matter? Changes in the diet of two Brazilian fishery communities. Ecology of Food and Nutrition
42:279-301.

Happold, D. C. D. 1995. The interaction between humans and mammals in Africa in relation to conservation: a review. Biodiversity and Conservation 4:395-414.

Hardesty, D. L. 1975. The niche concept: suggestions for its use in human ecology. Human Ecology 3(2):71-85.

Hawkes, K., K. Hill, and J. F. O'Connel. 1982. Why hunters gather: optimal foraging and the Aché of eastern Paraguay. American Ethnologist 9 (2):379-398.

Hutchinson, G. E. 1957. Concluding remarks: Cold Spring Harbor Symposium. Quantitative Biology 22:415-427.

Krebs, C. J. 1999. Ecological methodology. Second edition. Benjamin Cummings, San Francisco, California, USA.

Krebs, J. R., and R. H. McCleery. 1984. Optimization in behavioural ecology. Pages 91-121 in J. R. Krebs and N. B. Davies, editors. Behavioural ecology: an evolutionary approach. Blackwell Scientific, London, UK.

Kuhnlein, H. V. 1992. Change in the use of traditional foods by the Nuxalk native people of British Columbia. Ecology of Food and Nutrition 27(3/4):259-282.

Lopes, P. F. M. 2004. Ecologia caiçara: pesca e uso de recursos na comunidade da Praia do Puruba. Thesis. Universidade Estadual de Campinas, Campinas, Brazil.

MacArthur, R. H., and E. R. Pianka. 1966. On optimal use of a patchy environment. American Naturalist 100:603-609.

Magurran, A. E. 1988. Ecological diversity and its measurement. Cambridge University Press, Cambridge, UK.

McDonald, D. R. 1977. Food taboos: a primitive environmental protection agency (South America). Anthropos 72:734-748.

Messer, E. 1984. Anthropological perspectives on diet. Annual Review of Anthropology 13:205-249. 
Murrieta, R. S. S., E. Brondízio, A. Siquiera, and E. F. Moran. 1993. Estratégias de subsistência de uma população ribeirinha do rio Marajó-Açu, Ilha de Marajó, Brasil. Boletim do Museu Paraense Emílio Goeldi, Série Antropologia 5(2):147-163.

Murrieta, R. S. S., A. L. Dufour, and A. Siquiera. 1999. Food consumption and subsistence in three caboclo populations on Marajó Island, Amazonia, Brazil. Human Ecology 27(3):455-475.

Neiland, A. E. , J. Weeks, S. P. Madakan, and B. M. B. Ladu. 2000. Inland fisheries of North East Nigeria including the Upper Rive Benue, Lake Chad and the Nguru-Gashua wetlands. II. Fisheries management at village level. Fisheries Research 48:245-261.

Pelto, G. H., and P. R. Pelto. 1983. Diet and delocalization: dietary changes since 1750 . Journal of Interdisciplinary History 14(2):507-528.

Peroni, N., and N. Hanazaki. 2002. Current and loss diversity of cultivated varieties, especially cassava, under swidden cultivation systems in the Brazilian Atlantic Forest. Agriculture, Ecosystems and Environment 92:171-183.

Schläpfer, F., and B. Schmid. 1999. Ecosystem effects of biodiversity: a classification of hypotheses and exploration of empirical results. Ecological Applications 9(3):893-912.

Silvano, R. A. M. 2004. Pesca artesanal e etnoictiologia. Pages 187-222 in A. Begossi, editor. Ecologia de pescadores da Mata Atlântica e da Amazônia. Editora Hucitec, São Paulo, Brazil.

Siry, H. Y. 2006. Decentralized coastal zone management in Malaysia and Indonesia: a comparative perspective. Coastal Management 34 :267-285.

Smith, E. A. 1983. Anthropological applications of optimal foraging theory: a critical review. Current Anthropology 24(5):625-651.

Stephens, D. W., and J. R. Krebs. 1986. Foraging theory. Princeton University Press, Princeton, New Jersey, USA.

White, A., E. Deguit, W. Jatulan, and L. EismaOsorio. 2006. Integrated coastal management in
Philippine local governance: evolution and benefits. Coastal Management 34:287-302. 
Appendix 1. Indexes used to measure similarity and diversity.

\section{Please click here to download file 'appendix1.pdf'.}

